\title{
Seeking and finding emerging issues in management and governance
}

\author{
Roberto Di Pietra
}

Published online: 15 December 2009

(C) Springer Science+Business Media, LLC. 2009

On the occasion of the 30th Annual Conference of the Italian Academy of Business Economics (Accademia Italiana di Economia Aziendale, AIDEA) in 2007, the Journal of Management and Governance (JMG) was asked to organize a Symposium of its own. A few months after taking over the Editorship and renewing the boards, the co-editors and I decided to propose to participants in the AIDEA conference a symposium capable of outlining a prospective view of Management and Governance studies. Our intention was to seek to focus on the frontier of scientific debate regarding management and governance and, at the same time, attempt to trace the lines along which future studies may develop in the medium term.

For this reason we invited distinguished scholars to contribute their personal vision of the future of management and governance studies to the scientific debate. We also submitted these views to debate among other equally distinguished discussants.

We are firmly convinced that it is the specific task of a Journal to represent a place in which stimulating and lively scientific debate can evolve among scholars. In this sense, we have sought to orient the research efforts towards the emerging issues in management and governance, with the aim of focusing on its changing frontier.

On 19 October 2007 in Milan, Al Bhimani (London School of Economics), Randall Morck (University of Alberta), Henry Tosi (University of Florida) and their respective discussants (Thomas Ahrens-Warwick Business School; Lorenzo Caprio-Catholic University Milan; Igor Filatotchev-Cass Business School) began the process that has culminated in the publication of these contributions in the Journal of Management and Governance. In issue 2 of 2008 we were able to include all the contributions made on the occasion of the first JMG symposium in

R. Di Pietra $(\bowtie)$

University of Siena, Siena, Italy

e-mail: dipietra@unisi.it 
Milan (Di Pietra 2008; Bhimani 2008; Ahrens 2008; Tosi Jr. 2008; Filatotchev 2008; Morck 2008; Caprio 2008).

At the Milan Symposium a further call for papers was made with the aim of realizing a Special Issue on "Emerging Issues in Management and Governance". The Guest Editors of this Special Issue were Thomas Ahrens, Igor Filatotchev and Steen Thomsen (Copenhagen Business School), who have been working on it throughout 2008 and 2009.

Thus at the end of a long process, the Special Issue, which includes the articles that you can read in this issue of the JMG, has finally been published. The articles are prefaced by a seminal study by the three Guest Editors, in which Ahrens, Filatotchev and Thomsen have sought to chart the possible developments that can be anticipated over the next few years in the study of management and governance. As Editor I hope that this view offered to the scientific arena (which is what our Journal is and intends to be) may herald a second Special Edition on Emerging Issues in Management and Governance in the next few years, with the aim of further confirming, confuting and relaunching debate on the issues that inspire our Journal.

\section{References}

Ahrens, T. (2008). The hidden ethics of corporate governance and the practical uses of corporate governance codes: A commentary on Bhimani. Journal of Management and Governance, 12(2), $149-152$.

Bhimani, A. (2008). Making corporate governance count: The fusion of ethics and economic rationality. Journal of Management and Governance, 12(2), 135-147.

Caprio, L. (2008). How can we help independent directors to escape the "obedience bias?". Journal of Management and Governance, 12(2), 201-204.

Di Pietra, R. (2008). JMG first symposium on emerging issues in management and governance. Journal of Management and Governance, 12(2), 133-134.

Filatotchev, I. (2008). Developing an organizational theory of corporate governance: Comments on Henry L. Tosi Jr. (2008) "Quo Vadis? Suggestions for future corporate governance research". Journal of Management and Governance, 12(2), 171-178.

Morck, R. (2008). Behaviorial finance in corporate governance: Economics and ethics of the devil's advocate. Journal of Management and Governance, 12(2), 179-200.

Tosi, H. L., Jr. (2008). Quo Vadis? Suggestions for future corporate governance research. Journal of Management and Governance, 12(2), 153-169.

\section{Author Biography}

Roberto Di Pietra is a full professor in Accounting and Business Administration at the Department of Business and Social Studies, University of Siena, Italy, He gained a Ph.D. in Accounting and Business Administration from the University of Pisa in 1997, followed by a postgraduate specialization in Banking in 1993. Di Pietra's main research interests are in International Accounting (IAS/IFRS and Financial statements, IAS and corporate governance, accounting regulation, IAS and organizational learning), Auditing and Accounting History. 